University at Buffalo School of Law

Digital Commons @ University at Buffalo School of Law

\title{
Uprooting Identities: The Regulation of Olive Trees in the Occupied West Bank
}

Irus Braverman

University at Buffalo School of Law

Follow this and additional works at: https://digitalcommons.law.buffalo.edu/journal_articles

Part of the Law and Society Commons

\section{Recommended Citation}

Irus Braverman, Uprooting Identities: The Regulation of Olive Trees in the Occupied West Bank, PoLAR, Nov. 2009, at 237.

\section{C) ${ }_{\text {COPYRIGHT }}^{\text {N }}$}

This Article is brought to you for free and open access by the Faculty Scholarship at Digital Commons @ University at Buffalo School of Law. It has been accepted for inclusion in Journal Articles by an authorized administrator of Digital Commons @ University at Buffalo School of Law. For more information, please contact lawscholar@buffalo.edu. 


\section{Irus Braverman}

SUNY-Buffalo Law School

\section{Uprooting Identities: The Regulation of Olive Trees in the Occupied West Bank}

It is as though, by virtue of the derealization of Palestine, a project reaching back over 50 years, the roots of Palestinian violence - the dispossession of the Palestinian people, the dispersal of refugees, and the horrors of military occupation - have been torn up with their olive groves. [Gregory 2003:319]

Like children, their trees look so naïve, as if they can’t harm anyone. But like [their] children, several years later they turn into a ticking bomb. [Interview, Chief Inspector Kishik, Israel's Civil Administration, Beit El military base, September 7, 2006]

Trees in general, and olive and pine trees in particular, perform a pivotal role in both the Zionist and the Palestinian national narratives. Since 1901, the Jewish National Fund (JNF), an organization established by the Fifth Zionist Congress for purchasing land in biblical Israel, has planted over 240 million trees in Israel, most of which are pines. This massive enterprise has fundamentally transformed the Israeli/Palestinian landscape. Indeed, over the years, the pine has come to be perceived as the quintessential symbol of the Zionist project: through its rooting, the land of Israel has transformed into a European-looking landscape (Bardenstein 1999; Braverman 2009, in press.a; Cohen 1993; Long 2005; Zerubavel 1995). 


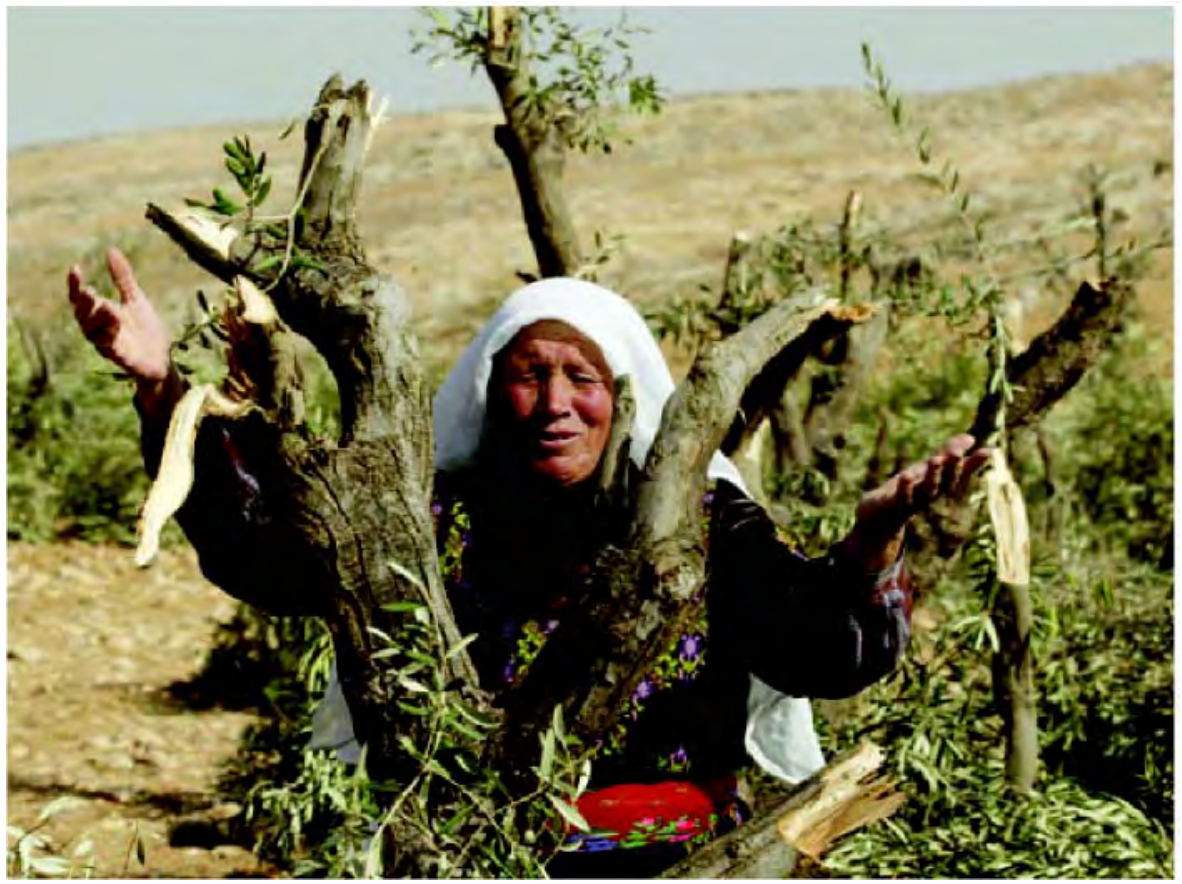

Figure 1. Palestinian woman lamenting the vandalization of her olive trees in Litwane, January 6, 2006, near the Jewish settlement of Ma'on. Source: REUTERS/Nayef Hashlamoun, 2006. Reprinted with permission.

If the Jewish tree is the pine, the Palestinian tree is the olive (see, e.g., Figures $1 \& 2$ ). As Ismat Shbeta, a refugee from the depopulated Palestinian village Miske, tells me in an interview, “The olive is the Palestinian tree... That's the olive’s nationality” (Interview, Tel Aviv, August 10, 2006). The olive and the pine seem to be perfect opposites, agronomically as well as culturally. Elsewhere, I have explored in depth both the pine's construction as the Zionist tree and the bifurcated relation between the pine and the olive, along with the range of contestations to this naturalized bifurcation (2009, in press.a, in press.b).

This article's focus is on the olive tree. Again, this is but one side of the much larger story of the tree wars performed in this region. The article studies the olive's various meanings within Palestinian culture as well as its targeting by the State of Israel and by 
certain Jewish settlers. I argue here that the identity of the olive as a representation of the Palestinian is not only the result of its economic, cultural, and historical significance within this particular culture, but is increasingly a product of the olive's brutal targeting by the State of Israel and by certain Jewish Israeli settlers. Through their direct and indirect acts of uprooting, sabotaging, and denying the Palestinians access to the olive tree, the State of Israel and the settlers have vested the olive with enormous power. At the end of the day, then, the various struggles conducted on the olive's behalf have enhanced the already significant status of the olive tree in various Palestinian narratives. The tragic story constructed around the olive has made this tree, more than ever before, into both the symbol and the embodiment of Palestinian nationhood--and, perhaps more importantly, into a manifestation of Palestinian resistance to Israel's occupation.

At the same time, the article also demonstrates how humanitarian initiatives enacted by the State of Israel to protect Palestinian olive cultivation have led to an even tighter, yet also more discrete, system of surveillance of Palestinians in the West Bank. The system is enforced through close monitoring by Israel's Defense Forces of the Palestinians' concept of space and time, mainly through the newly established regime of "friction zones" and "timetables." The tight security administration imposed through the regulation of the Palestinians' olive-related practices has thus taken over their everyday relationship with their land. The project of Palestinian resistance through rooting olives into the land has, in other words, been flipped on its head and has morphed into yet another means for Israel's assertion of occupation and control in this place. 
Generally, this article is situated within the literature of Law and Geography, which focuses on an exploration of the intricate connections between law and space (see, e.g., Blomley 1994; Blomley et. al 2001; Delaney 1998). My study offers a more material focus within this literature. It highlights both the physical and the imaginary spatialities of olive trees. It also demonstrates how the identity of these trees and the establishment of their meaning have manifested and changed through a set of government policies, court decisions, and military regulations.

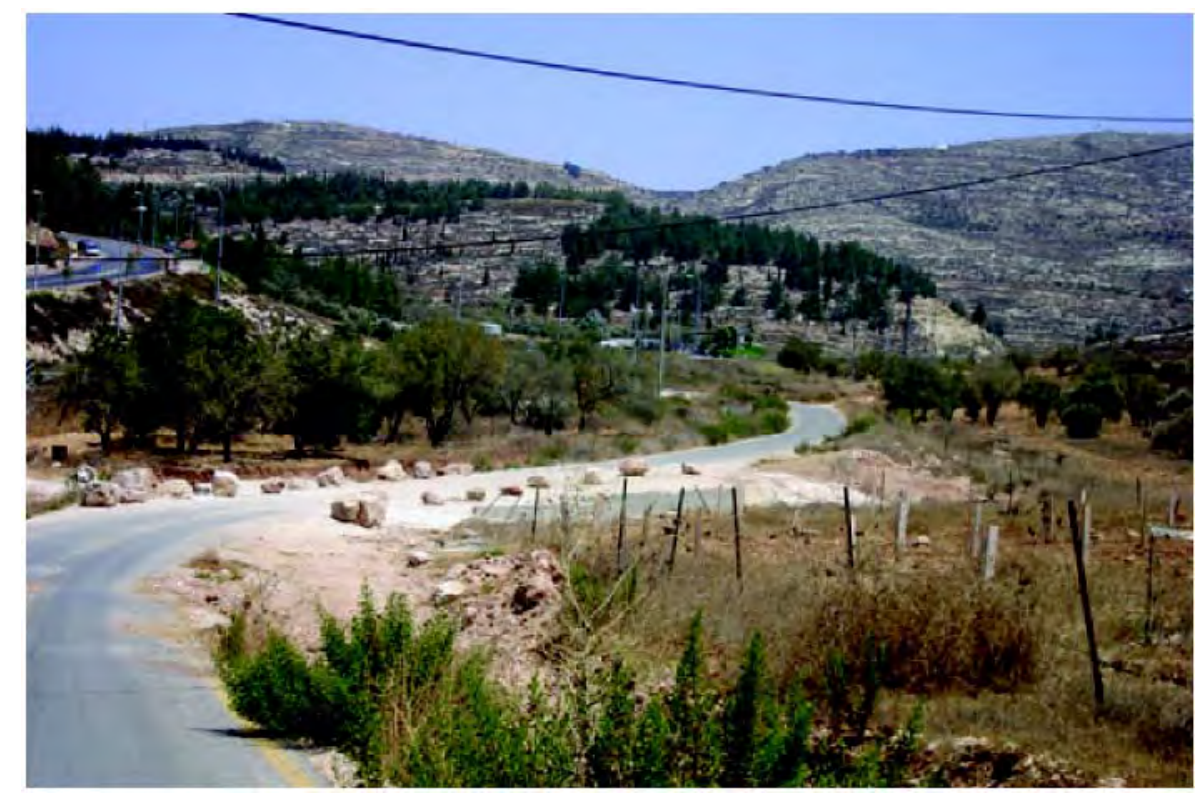

Figure 2. Olive trees (foreground) and pines (background) in the northern West Bank. Photo by author, August 2006.

The article begins by describing the significance of the olive for the Palestinian, which ranges between its identity as a shajara fakir (pauper's tree) and its identity as a shajara mubaraka (holy tree). This part of the article focuses on the Palestinian act of "rooting," and even clinging, to the land, performed through the olive tree. Thus the olive here not merely stands for but also embodies the Palestinian. Next, the article focuses on the olive’s “uprooting." Specifically, it explores two instances of olive uprooting: the State of 
Israel's massive uprooting of olive orchards in order to make way for the Separation Barrier and the publicly contested uprooting and sabotaging of olive trees by certain Jewish settlers. In both instances, the olive's erasure from the landscape is perceived as necessary to make space for an alternative and exclusive Jewish presence. Parallel to the olive's direct obstruction through uprooting, the final section of the article identifies another, much less direct, form of control of the Palestinian's relationship with the olive-this time through Israel's enactment of a diffuse regulatory network of "friction zones" and "timetables."

The article is based on a series of semi-structured, in-depth interviews and also on participant observation with the following: Palestinian fellahin (Arabic for farmers; see also Swedenburg 1990); members of a radical group of Jewish Israeli settlers; officials in Israel's Military Administration of the West Bank - which since 1981 also includes Israel's Civil Administration; and members of human rights organizations such as Rabbis for Human Rights, The Association for Civil Rights in Israel, B’Tselem, and Yesh Din. The interviews and observations were conducted during the winter of 2005, the summer of 2006, and the spring of 2008.

\section{Between Shajara Fakir (Pauper’s Tree) Shajara Mubaraka (Holy Tree)}

A. The olive industry is considered one of the most important agricultural vegetations in the area of Judea and Samaria, and a central source of living for most of the villages in this area; ...

C. The olive harvest is a socio-economic event in Palestinian society, and the days of harvest are considered a holiday in which the entire family engages.

Although these words could be taken from a book discussing Palestinian culture, they are

actually from a leaflet produced by Israel’s Civil Administration for Judea and Samaria 
that was distributed widely among soldiers of Israel's Defense Forces deployed in the occupied West Bank during the harvest season of 2005. This section explores how such an unexpected source of information about Palestinian harvest culture came to be.

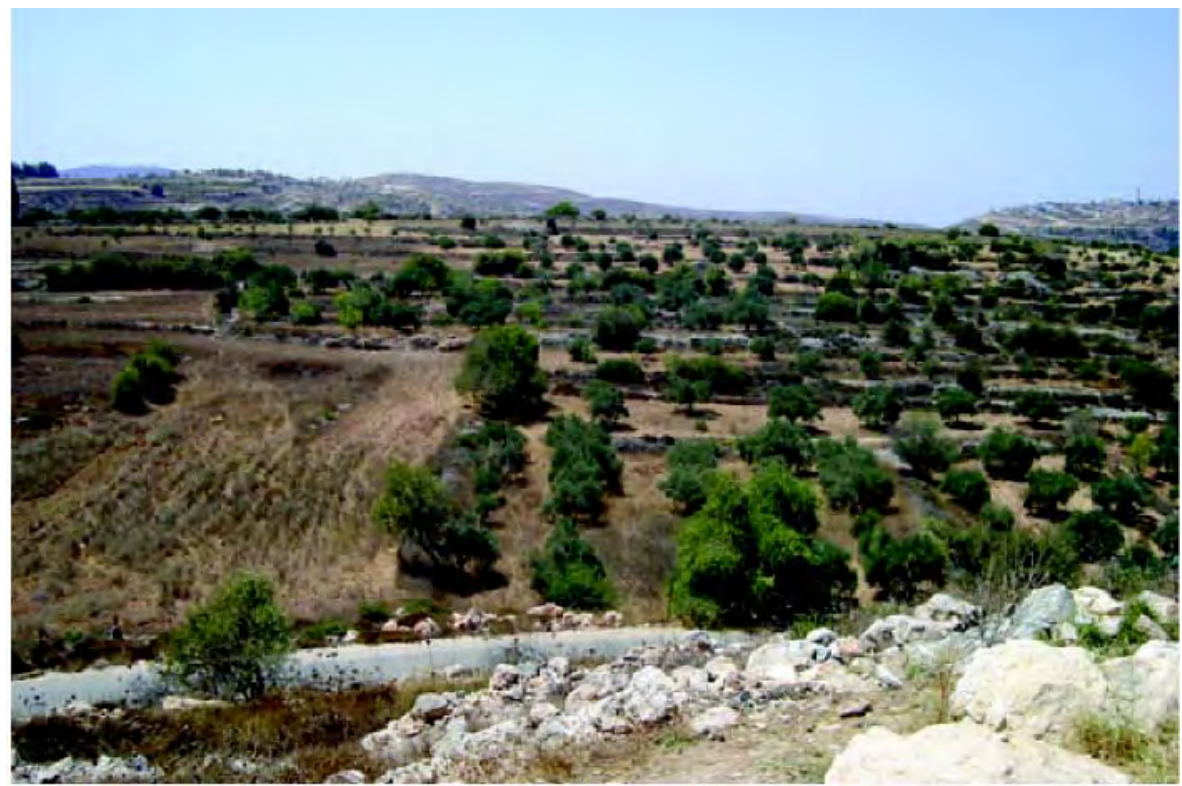

Figure 3. Olive groves in the occupied West Bank. Photo by author, August 2006.

Approximately 45 percent of arable land in the occupied Palestinian territories (including the Gaza Strip) is planted with olive trees. ${ }^{1}$ Most of the olive groves are located in the West Bank, where the olive industry accounts for approximately 40 percent of the total value of agricultural produce and for 70 percent of the production from fruit trees. More than 70,500 farmers own olive trees, and many more depend upon various activities associated with the trees for their livelihood. Some 90 percent of the olive crop is designated for oil, which is processed in 194 olive presses situated throughout the occupied Palestinian territories. The size of the olive harvest varies from year to year, but usually corresponds with a biennial cycle, characterized by a high yield in one year and a 
low one in the next. Most olive-related activities occur during a two-month period in the fall, which is also known as the olive harvest season.

The importance of the agricultural sector at large and of the olive industry in particular in Palestinian society has increased significantly since the beginning of the second Intifada in 2000. Before this time, many rural residents of the occupied West Bank were employed in Israel. But Israel's severe restrictions on movement since the second Intifada have caused many to lose their jobs. The increase in unemployment - now more than 50 percent of the workforce - has gradually increased the number of Palestinians whose livelihoods depend on local sources of income, and chiefly on their ability to complete the economic cycles of olive oil production: harvesting the olive fruit, extracting the oil, and selling it. As recorded by the human rights organization B'Tselem on October 3, 2002, Muhammad Ubeid's testimony demonstrates the economic importance of the olive industry:

When I became unemployed, olive picking turned into the principal source of income for others in my family and me. During last year's harvest, my brothers and I picked olives even though there weren't many on the trees.... This year, the olives are plentiful, so we expect a large harvest. All the village residents are relying upon this season's harvest, because unemployment has been rampant in the village. So olive picking has become almost our sole source of income. [Testimony, B'Tselem 2002] ${ }^{2}$

Similarly, several Palestinians interviewed for this study refer to the olive tree as Shajara el-Fakir, or "the pauper’s tree”: “you don’t give it anything and it gives you everything in return,” they say (Interview, Rashid in Yanun village, August 21, 2006). But as Rabbi Ascherman, executive director of Rabbis for Human Rights, explains, the significance of the olive to the Palestinian goes far beyond economics: 
In recent years [the olive] has an increasing cultural and symbolical importance and is less an economic thing. It's about the ties to the land and the entire family going out and harvesting together.... Sometimes people don't care that much about their olives, [and] it's just a way to show their connection to their land. [Telephone interview, December 23, 2008]

Indeed, Rabbi Ascherman stresses that Palestinians have been using the olive trees to strengthen their territorial claims. Such claims are frequently grounded in the principle of sumud. Sumud, meaning steadfastness or steadfast perseverance, is a political strategy of resistance that first emerged among Palestinians through the experience of the occupation in the wake of the 1967 war (Nassar and Heacock 1990: 28). Accordingly, Nabil, a fallah (farmer) from Akraba, tells me, "The olives are my life. [They are] my soul. My olives are like my children.” This form of intense identification is a necessary stage in constructing the interchangeability between the material olive tree and the body of the Palestinian.

Later that day, I ask a large group of Palestinian farmers why the olive tree is so important to them. Two of the farmers - Rashid from Yanun and Zakaria from Jit explain that the Quran regards the olive as one of two trees blessed by Allah (the other is the fig). This, they say, makes the olive a shajara mubaraka: a holy tree. But the farmers all agree that the olive tree is not important only in itself. Nabil explains that "it's the land. The land is the most important thing... I will never give it up. El ard, we'el ard wahid (the land, and the land only)" (Interview, Akraba village, August 21, 2006). This statement explicates the project of resistance embodied in the Palestinian act of cultivating the olives: more than anything, the olive has thus become an act of steadfast resistance to the Israeli occupation. 


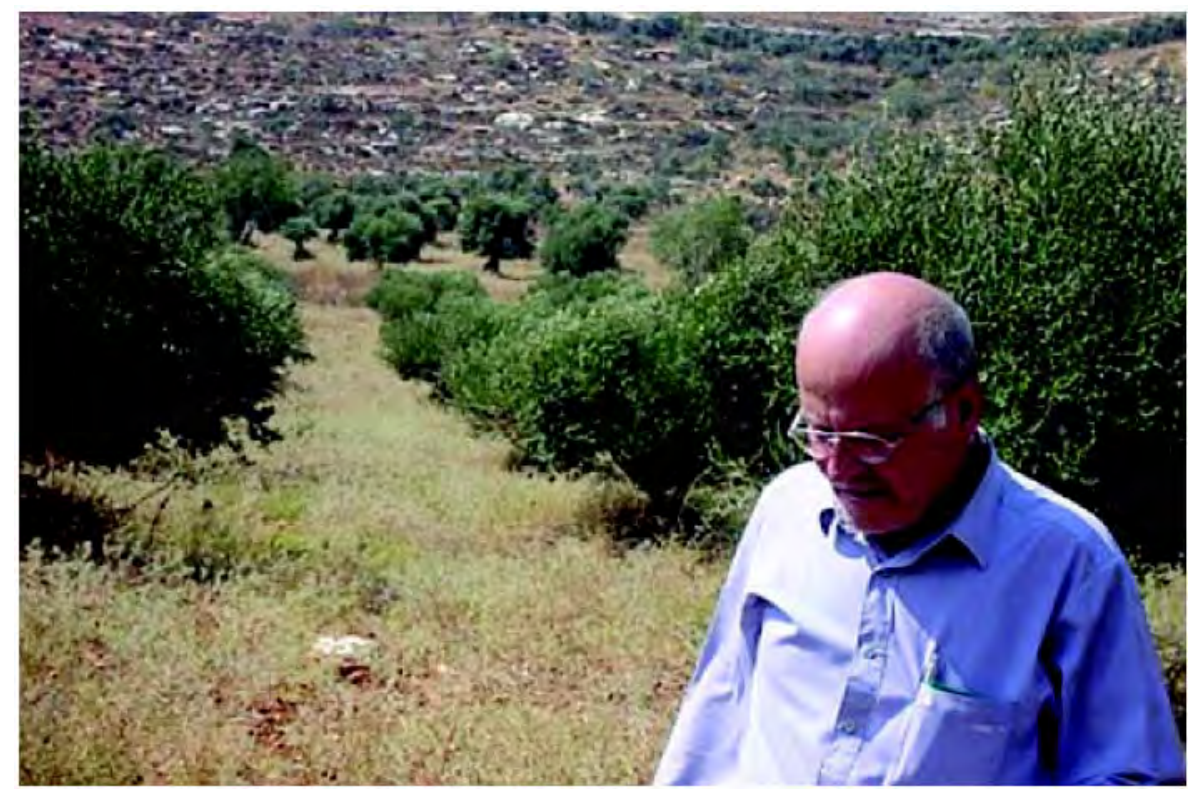

Figure 4. Nabil, a Palestinian farmer, near his olive grove in the occupied West Bank. Photo by author, August 2006.

A similar notion is aptly phrased in a completely different context by David Kishik, Chief Inspector in Israel's Civil Administration of the occupied West Bank, who tells me that, “The olive tree is one of the best ownership techniques around.” The olive's uniqueness, Inspector Kishik further explains, is based on its cultural and economic significance and is tied to its particular physical features (Interview, Beit El military base, September 7, 2006). Suliman Shahin, a Palestinian lawyer who has represented numerous Palestinians in a variety of land claims against Israel, says more about the physical features of olive cultivation:

What does it mean to cultivate an olive tree? You don't need to do much to cultivate an olive tree, you need to come in September and prune, and then three months later to harvest.... Other trees need a much more serious presence.... Such a [military] system does not allow growing anything else but olive trees. It's a catch-22, you see: we have many cases where people can't access their land, so what will they grow on it but olive trees? The olive is the only tree that can survive on its own, and it is also the Palestinian's agricultural symbol par excellence. It has become this way. [Interview, Jerusalem, December 23, 2005; emphasis added] 
Indeed, the Palestinians interviewed here stress that, more than any other tree or animal, the olive tree has come to symbolize the Palestinian people and their quest for independence. This is aided by the olive's particular physical features. The olive's steadfastness, durability, and extraordinary longevity (some say that olive trees can survive for thousands of years) have become symbols of the Palestinian struggle against the Israeli occupation and for national independence.

However, Zionist narratives refer to the olive's same steadfastness and durability as indicators of the unproductive nature of its Palestinian cultivators and, in particular, as illustrative of the Palestinian's unsuitability for engaging in more sophisticated forms of cultivation. This notion is described and criticized by Michael Sfard, a Jewish Israeli lawyer who has represented several Palestinians in petitions against Israel's Separation Barrier:

[Zionists have] a certain fixation that the Palestinians have only a very superficial relationship with their land: they come only once a year and then leave. This blends in well with the stereotype of the lazy Arab that sits under the tree all day: the goats come to him and give him their milk, and the olives, when they don't fall on his head, he might need to shake the tree lightly so that they fall in his lap.... You see this in the Zionist discourse for over a hundred years: they [the Palestinians] are portrayed as lazy people. This very superficial perspective creates a huge cultural misunderstanding about the Palestinians' relationship to their land. [Interview, Jerusalem, August 9, 2006]

Sfard's account provides a clear, if somewhat cynical and overstated, description of the stereotypical Zionist perception of the Palestinian farmer. To this he adds that, for Palestinian culture,

land is not only a source of livelihood. It is not only a factory for food. Land is a part of the identity of the people. The seasons, the holidays - are all dependent upon things that bear a connection to the land. And when you prevent these people from harvesting, it's like putting them under 
house arrest: you're preventing them from doing something that is part of their cultural world. Land is part of their identity. [Interview, Jerusalem, August 9, 2006]

Sfard's account may help explain why, for the Palestinian, the olive has become such a patriotic emblem, imbued with so much nostalgia and yearning.

Palestinian art frequently reflects the olive's nationalistic dimensions. Several Palestinian poets in particular have placed the olive at the forefront of grassroots resistance to the Israeli occupation, calling this "resistance poetry" (Harlow 1987: 70; see also Kanafani 1958). The following three excerpts are from Palestinian poems that relate to the olive tree as a vehicle of Palestinian nationalism and resistance:

The sun reproached us

It came, as usual,

Asking us to be patient

To remain like olive branches -

Deep in the soil

Are the roots of the olive tree -

To remain

Like the roots of the olive tree.

[As'ad al-As'ad, in Ashrawi 1978: 91]

Lightning, thunder, prayer

Hurricane, storms,

And floods break the branches

Of trees.

Ropes of earthworm

Trim the leaves of youthful olive trees

But the roots of the olive

Return and stretch in the depth

Of the soil... 
Roots of olive, you have become the model

And man is competing, imitating your root,

Olive of the land.

[Mahmoud Awad Abbas, in Ashrawi 1978: 91]

I shall carve the record of all my sufferings, and all my secrets,

On an olive tree, in the courtyard, of the house...,

I shall carve the number of each deed of our usurped land.

The demolished houses of its people, my uprooted trees, ...

And to remember it all,

I shall continue to carve all the chapters of my tragedy,

and all the stages of the disaster, from beginning to end,

On the olive tree, in the courtyard, of the house.

[Tawfiq Zayyad, in Bardenstein 1998: 28]

Even more tragic is Casualty 18 by late Mahmoud Darwish. This poem marks the 1956 massacre of fifty Palestinians from the Israeli Palestinian village of Kfar Kassem during Israel's military rule over areas with a large Arab Israeli population between 1949 and 1966. Not realizing that the Israeli army had changed the curfew by several hours, the workers returned home from work outside the village and were all shot and killed on sight. The poem is written from the perspective of one of the dead men, whose wedding was to take place several days later. In the poem he addresses his bride:

The olive grove was once green, At least it used to be.... and the sky was a blue forest... at least it used to be, my love What changed it that evening? The olive grove was always green. At least it used to be, my love. 
Fifty victims, at sundown

Turned it into a red pool...fifty victims.

[Mahmoud Darwish, in Bardenstein 1999: 153-154]

Of the large body of Palestinian poetry that uses the olive tree as a symbol of the Palestinian struggle, these four poems illustrate the idea of the olive tree as a living memory of the Palestinian village and its people and as a silent witness of their suffering (Bardenstein 1998: 28). The olive is depicted as growing where drops of Palestinian blood have been spilled, standing for the Palestinian by bearing witness for what has been erased and is no longer there. Numerous other Palestinian accounts refer to the olive as an embodiment of the Palestinian's absent condition (see, e.g., Farah 1963). In this very literal sense, the olive, still firmly rooted in the land from which its planter was uprooted, re-presents the Palestinian.

The olive tree, among other orchard trees, also figures prominently in Palestinian attempts to construct memory maps of villages that were depopulated and destroyed during the 1948 and 1967 wars. Although most of the houses in these villages were demolished, the trees and vegetation sometimes survived. In these circumstances, the trees have served as an anchoring device (van der Sluijs et. al 1998) for the exiles who visit these places seeking signs of their families' previous life there (Bardenstein 1999: 157; Slyomovics 1998).

A fusion of humans and trees is thereby constructed: the olive embodies the Palestinian people, the green of its foliage is perceived as interchangeable with the red of their blood. However, the olive is not only a proxy witness (Bardenstein 1999: 156); it also provides a model of survival for the Palestinian people. In this sense, the olive not only stands for 
but also speaks for the mute and uprooted Palestinian (contrary to the more usual case whereby humans speak for things; see, e.g., Callon 1986).

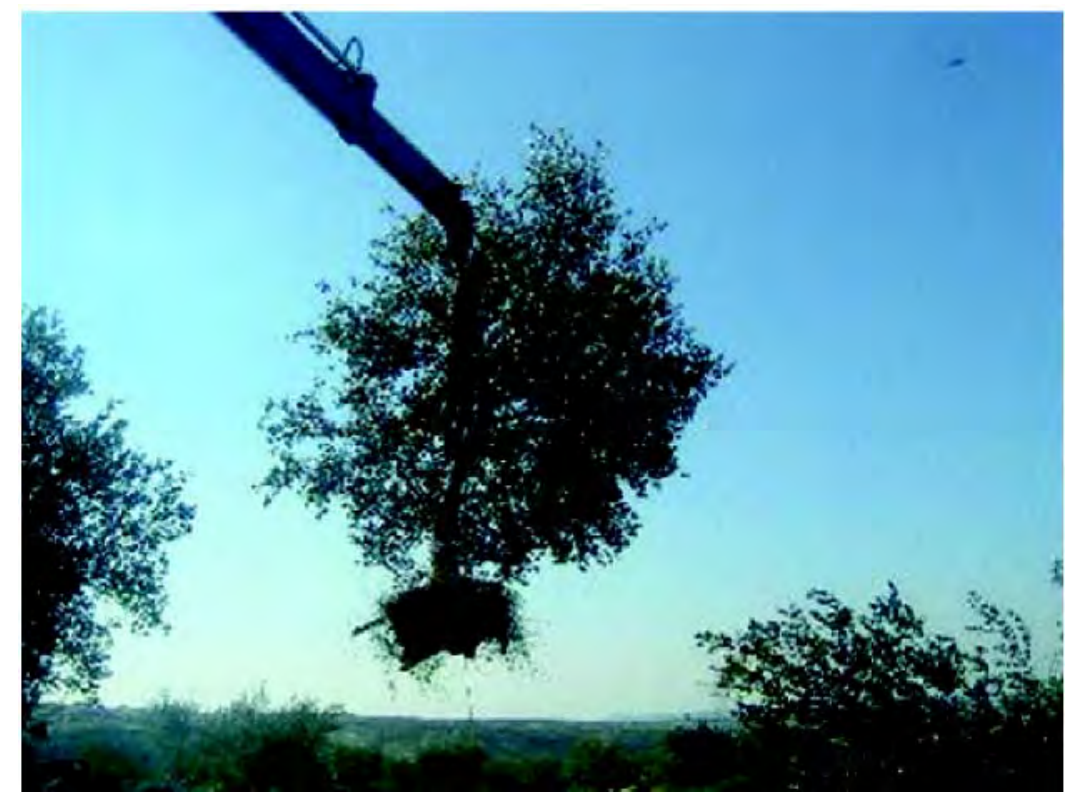

Figure 5. Suspended in space: the uprooting of olive trees for the expansion of Zufin, a Jewish settlement in the Tulkarm district. Source: B'Tselem; photo courtesy of Christoph Gocke - EAPPI. Reprinted with permission.

\section{Olive Uprooting: The Wall against the Olive}

Up until now I have explored the powerful meanings of olive uprooting to Palestinians and its significance in the project of resisting the Israeli occupation, which is also heavily focused on territory and land (Weizman 2007). Now, I would like to explore Israel's project of uprooting this same tree, an act that can only be understood in light of the previous discussion.

Since its inception, and increasingly in the last two decades, Israel has been uprooting Palestinian olive trees. The use of tree uprooting as a punitive measure predates the establishment of the State of Israel; it was used by Ottoman rulers against the fellahin as punishment for tax avoidance and was later implemented by the British Mandatory 
administration in Palestine through its emergency regulations (Cohen 1993; Bardenstein 1998: 10). However, Israel's central rationale for uprooting olive trees in the occupied territories has not been framed as punitive, or at least not explicitly so. Israel explains these uprootings, rather, as essential for its national security. First, Israel has been uprooting olives to make way for the recently built Separation Barrier. In the same vein, Israel's Defense Forces have uprooted thousands of olive and other fruit trees, and continues to do so, to secure roads, increase visibility, and make way for watchtowers, checkpoints, additional roads, and security fences around Jewish settlements (see, e.g., Figure 5 as well as Ha'aretz 2006c).

However, the form of olive uprooting that has probably received the most local and international attention is that performed in the occupied West Bank not by the Israeli government but by certain Jewish Israeli settlers. At least on the face of things, this form of uprooting is against the official Israeli policy. I focus this section on the practice of olive uprooting that has taken the largest quantitative toll: that conducted in the process of Israel's construction of the Separation Barrier. The next section explores uprooting by settlers.

In 2002, the State of Israel began the project of constructing the Separation Barrier through the entire West Bank to separate Jewish settlements and Israeli cities from Palestinian towns and villages (Weizman 2007: 161). Completed in August 2003, the first section of the Separation Barrier stretches over 125 kilometers (80 miles) and consists of an electrified fence with roads, trenches, and barbed-wire fences on each side. The barrier's width (which includes the roads, trenches, and barbed-wire fences) ranges between 50 and 100 meters. Along eight kilometers of this section of the barrier, Israel 
has also built an eight-meter-high concrete wall. Finally, some 80 percent of this section is located east of the Green Line (the internationally recognized border), thereby isolating Palestinian villages and agricultural areas from the rest of the West Bank (cited in B’Tselem 2004).

After a series of re-routings, the current route of the barrier was approved by the Israeli government in April 2006. According to this 723 kilometer-long route, 8.5 percent of the West Bank territory and 27,520 Palestinians are on the "Israeli" side of the barrier. Another 3.4 percent of the area (with 247,800 inhabitants) is completely or partially surrounded by the barrier. ${ }^{3}$ 


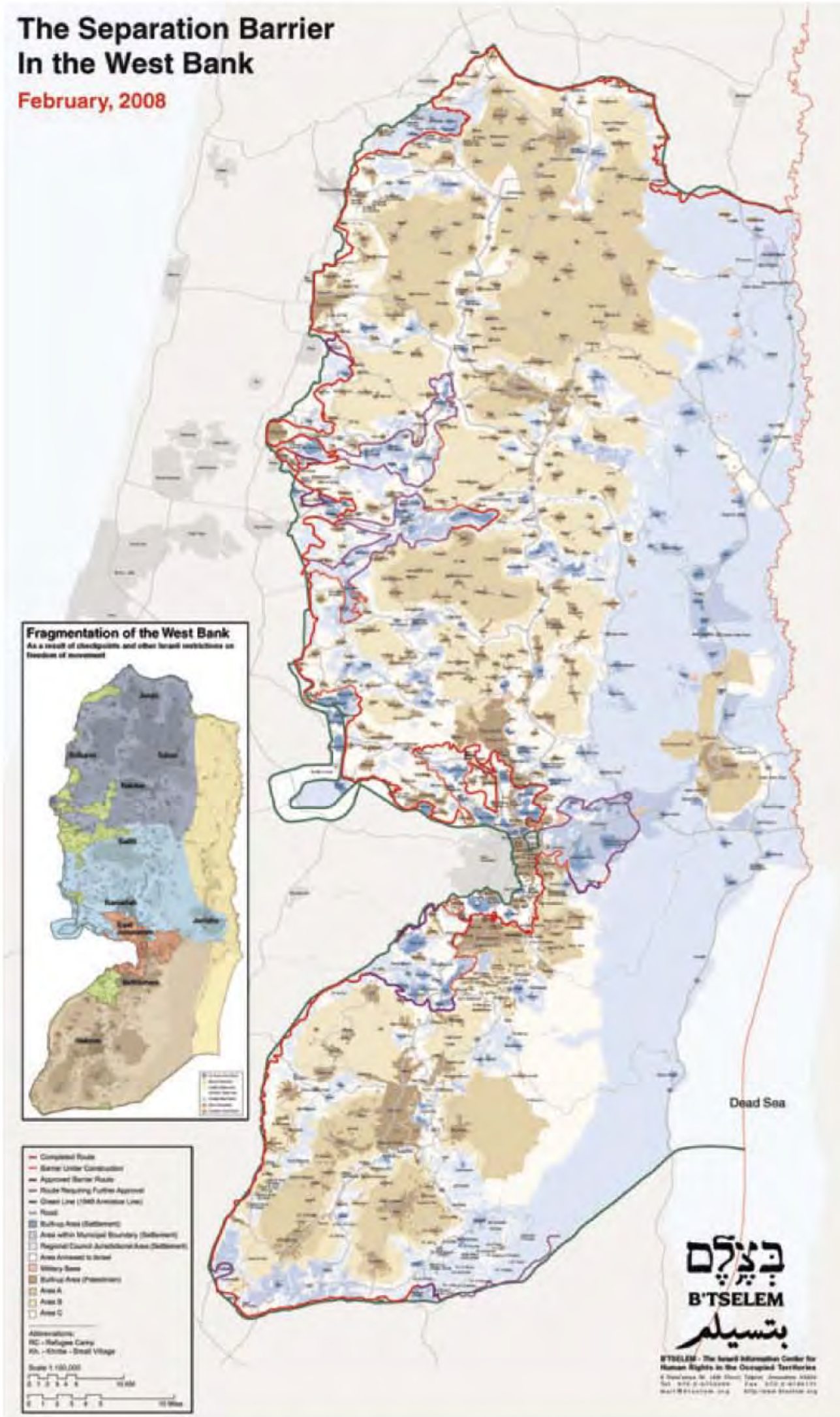

Figure 6. Map of the Green Line (west), the Separation Barrier (east), and the seam area in between, in the Tulkarm-Qalqilia area, West Bank. 
Tens of thousands of olive trees have been uprooted to make way for the Separation Barrier (Telegraph 2002). In the village of Qafeen alone, for example, 12,600 olive trees were uprooted for this purpose. An additional 100,000 olive trees situated on lands owned by Palestinians from this same village were trapped behind the barrier in what have been defined as "seam zones." Their owners are prohibited from accessing them most of the year, so that "[a]ll they can do is gaze on the neglect from afar" (Ha'aretz 2006c).

Although the uprooting of olive trees to facilitate the construction of the Separation Barrier initially caused some unease among the Israeli public, soon the security rationale supporting the barrier prevailed. However, under international pressure, the Israeli government assured that it would re-plant all uprooted olives. Suliman Shahin, the Palestinian attorney discussed above, addresses the assumption behind this re-planting:

[Since] it's a tree, they depict it as something that can be transplanted, which makes it seem like no fundamental harm was done. Do you understand? They say that the root of the tree is not necessarily connected to this place but could instead be rooted anywhere else; they even say that we can benefit from it. [Interview, Jerusalem, December 23, 2005]

However, apparently not all the olive trees have been transplanted. In December 2005, popular Israeli daily Yediot Achronot printed a news story about an owner of a contracting company who offered two undercover reporters one hundred large olive trees for the price of $\$ 400$ each. The reporters also found a 600 -year-old olive tree on sale for $\$ 8,000$ in an Israeli tree nursery. It was insinuated that the Israeli Civil Administration was somehow involved in these commercial activities (Yediot Achronot 2005). 
As a result of the public outcry triggered by these stories, Israel's Minister of Defense launched a public investigation into this issue (Telegraph 2002). Since then, Israel's Civil Administration in the West Bank has been devoting much care to replanting the trees according to requests by their owners, or in temporary locations until the owners can themselves replant them (see, e.g., Figure 7). The official website of Israel's Ministry of Defense states, accordingly, that

farmers who cultivate olive and other fruit trees growing within the Security Fence can designate a new site to which the trees will be relocated which has no free access constraints. Contractors assigned by The [sic] Ministry of Defense to build the Security Fence are responsible for carefully uprooting and replanting the trees. So far over 60,000 olive trees have been relocated in accordance with this procedure. [Israeli Ministry of Defense n.d.]

Attorney Suliman Shahin provides a different perspective about the aftermath of this "olive scandal":

Following the media exposure, the army now suggests to replant the uprooted olive trees, but only if the Palestinian owner gives his consent. Meanwhile, they plant the trees on state land until someone demands something else. Or sometimes they uproot the trees but keep them in place, watering the roots until the owners decide what to do. But in many cases the owner can't offer an alternative site, simply because he doesn't have one. What can he do, really? He can't ask friends to plant the trees in their land and cultivate it there - they would never agree! It's very complicated, and it's all lip service on their part. [Interview, Jerusalem, December 23, 2005] 


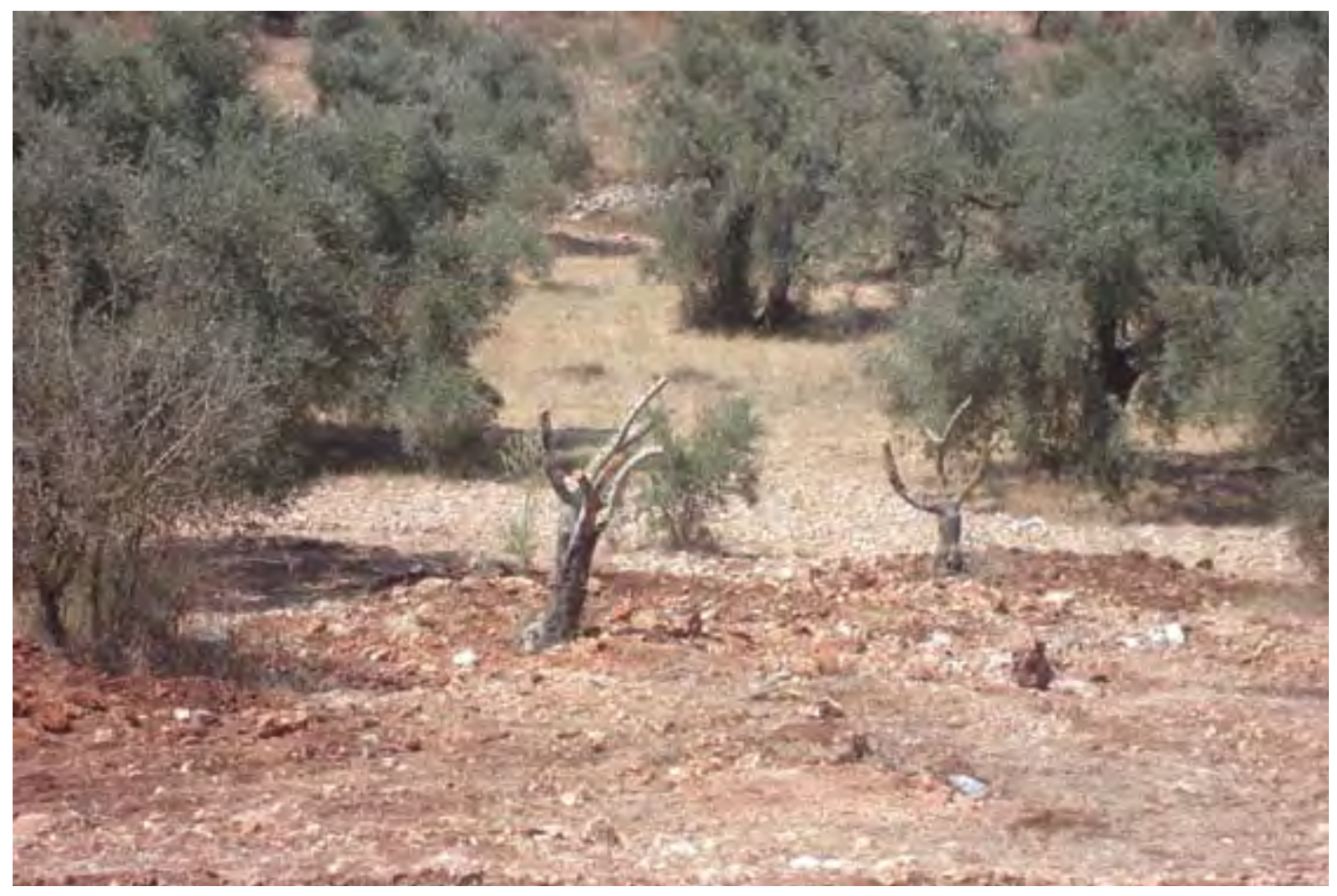

Figure 7. Uprooted olive trees, replanted in the margins of a state road near the city of Qalqilia in the occupied West Bank. Photos by author, August 2006.

\section{Olive Warfare: Uprooting by Settlers}

In addition to the uprooting of Palestinian olives by the State of Israel, for the last decade or so Jewish settlers have also been targeting Palestinian olive trees. Those mainly responsible for this targeting are the New Settlers - a term that I use to distinguish the more radical and largely messianic group of settlers, who live in distinct outposts (declared by the State of Israel to be illegal), from the large majority of Jewish settlers (see also Braverman 2008). The tree warfare conducted by the New Settlers adds another layer of meaning to the relationship between humans and trees in the occupied West Bank. Consider the following report:

According to the (incomplete) list of 29 incidents of agricultural sabotage documented by the human rights groups Yesh Din and B'Tselem from March to December, a total of 2,616 trees were sabotaged: uprooted, 
stolen, burned, chopped, sawed. In Salem alone, 900 trees were uprooted four times. [Ha'aretz 2006c]

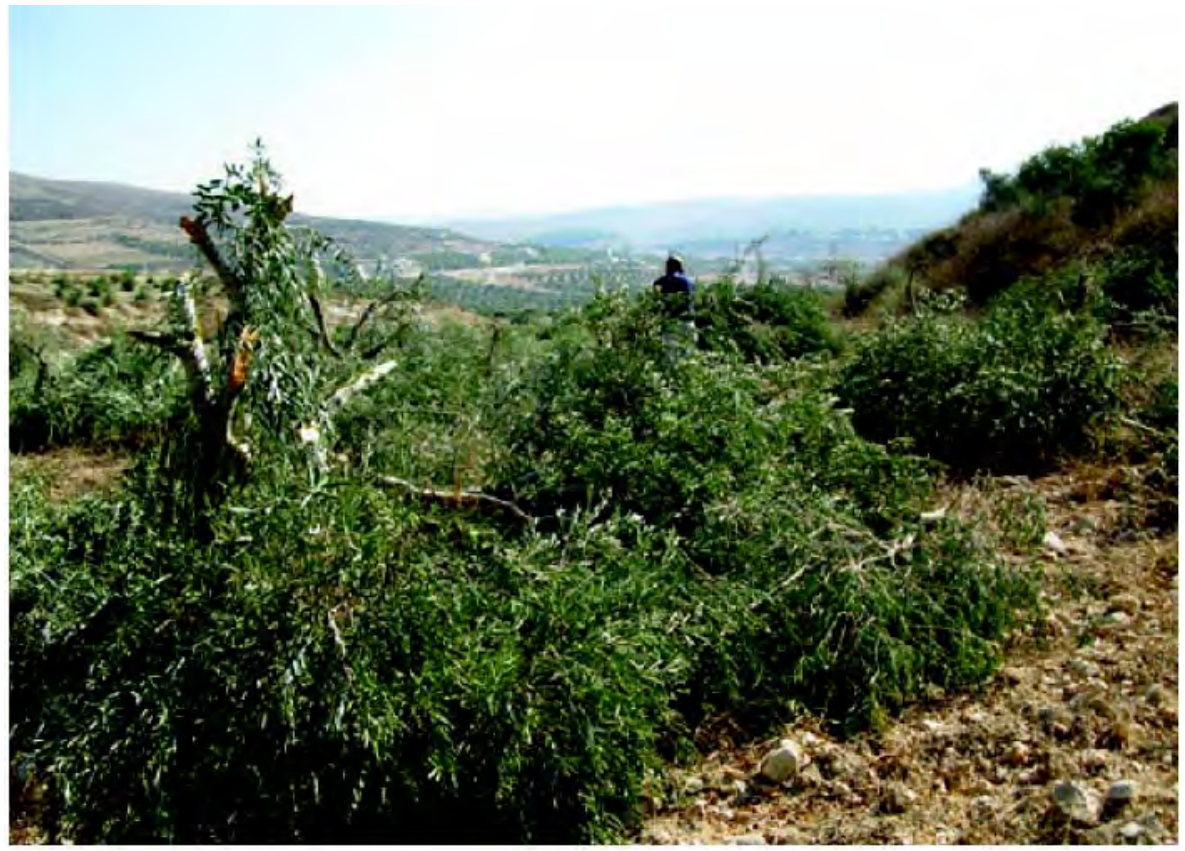

Figure 8. Olive trees near Burin village damaged by settlers from nearby Yitzhar. Yom Kippur, September 15, 2009. Photo courtesy of Yesh Din. Reprinted with permission.

Some three years later, B'Tselem recorded this testimony from Ziad Sawan, a 53-yearold resident of Immatin (Qalqilia district) and father of ten:

I have a few plots of land that I inherited from my father. About six years ago, settlers established Gilad Farm about two kilometers from one of my plots. Since then, they have attacked farmers in the area and torched and cut trees. Last spring, they set fire to orchards in the area, and the fire spread to my land. As a result, I lost many olive trees and lots of money during the harvest season. I filed a complaint, but nothing came of it. A little while later, at the checkpoint, my permit to work in Israel was taken from me, and now I'm unemployed. I think they took it because of the complaint I filed. [Testimony (Jan. 21, 2009), B’Tselem n.d.b]

According to Rabbi Ascherman, the summer of 2008 has seen a dramatic incline in the number of olive trees burnt, uprooted, and stolen by settlers - all part of Tag Mechir (Operation Price Tag), launched by the New Settlers around that time in retaliation for outpost evacuations (Telephone interview, December 23, 2008; see also Ha'aretz 2008b; 
McClatchy Newspapers 2008). According to Ascherman, since operation Price Tag began, settlers have uprooted and set fire to thousands of olive trees. On June 2, 2009, B’Tselem called on Israel's Defense Minister to prepare for acts of violence by settlers following Israel's decision to evacuate outposts. B'Tselem also demanded that security forces fulfill their obligation to allow Palestinian rescue and fire services freedom of movement, or, alternatively, that they evacuate the injured and extinguish the fires. ${ }^{4}$

Conducted and articulated through the olive tree, the everyday land struggles between Jewish settlers and Palestinians are also visible in the following instance. In December 2005, I observed the criminal trial of six young girls from several Jewish outposts near Beit El, who were indicted for attacking Palestinian harvesters in the village of Sinjil, north of Ramallah, and damaging their olive trees. According to the indictment, the six, together with four other girls whom the Palestinian plaintiff could not identify, "began to shove the farmers, hit them with sticks and throw stones at them." When an Israeli soldier tried to intervene, "the accused attacked him and beat him with their fists." The girls were also accused of pulling the headscarves off the women harvesters, punching one in the face, and taking an elderly man’s walking stick and shoving him.

During a break in the court hearing I briefly spoke to one of the girls, who was fourteen years of age at the time. When I asked her why she damaged the trees, the girl replied confidently, "I have nothing against the trees; this is about the land - it's our land, not theirs.” The girls' defense attorney, whom I interviewed separately both before and after the court hearing, further suggested that the girls "are fair enough to give [the Palestinians] a sort of early warning that now we are harming your trees, but next time we will harm you." Conflating humans and trees, the girls' lawyer presented the 
uprooting of trees as a humane act, an act that spares humans from the harsh treatment that is, instead, inflicted on trees. The lawyer concluded the interview by asking me rhetorically, "What do you think is more important, people or trees?”

Rabbi Arik Ascherman, executive director of Rabbis for Human Rights, interprets the settlers' act of uprooting very differently. Namely, he notes the conflation between humans and the arboreal and the use of this conflation as a legitimizing factor for damaging Palestinian trees. Rabbi Ascherman also tells me that many Jewish settlers oppose the damaging of Palestinian trees. However, this opposition is usually based on the sacredness of trees in Jewish tradition, rather than on the harm inflicted on the Palestinian people. Indeed, secretary of Jewish settlement Maon, which is located in the southern West Bank, has harshly condemned the uprooting of olive trees. "As settlers and farmers," a news statement quotes him saying, "our way is not to destroy and uproot, but to build and plant” (Ha'aretz 2006b). Similarly, when replying to online questions on a Jewish Orthodox website, Rabbi Zalman Melamed, the former head of Yesha Council of Rabbis (the prominent settler organization), stresses that cutting olive trees is prohibited by Jewish law, "unless the trees serve as hiding places for terrorists, and in that case they should be cut down for security reasons” (Ha'aretz 2006b).

The reports about Jews harming olive trees elicited much shock among Jewish communities around the globe. In an interview, a Toronto board member of the local chapter of JNF explains some of the underlying reasons for his shocked response. "What I am going to say is inhumane," he warns me in advance, and then he proceeds to illustrate in gory detail how he would "gladly" carpet-bomb a large crowd of "Arabs" because "they all want to exterminate the Jewish people." At the same time, he also 
expresses utter dismay that Jews would target what he calls “Arab trees.” In his words, "I am ashamed that Jewish people can do this. They should go after the people, not after their trees” (Interview, Toronto, June 13, 2005).

Public commentary in the online edition of the Israeli newspaper Ha'aretz validates the moral differentiation between humans and trees. These responses emphasize how upsetting it is for Jewish people when "innocent trees" are targeted for uprooting, especially by fellow Jews. Some comments even go so far as to compare this behavior with that of the Nazis and the Ku Klux Klan: “I can't believe this,” says one North American Jew, “we didn’t survive the Holocaust so we can do things like this!” A second commentator argues that "cutting [olive trees] down is like the KKK burning crosses" (Ha'aretz 2006a, 2006c).

Another response to the news about Jewish settlers intentionally damaging olive trees has been outright denial. The common claim in this regard is that the Palestinians have been imposing such damage on themselves. This claim has soon developed into a forensic battle. According to Arutz-7, a right-wing Israeli newspaper,

Meanwhile, police forensics units have once again entered Samaria's olive groves to determine whether olive trees have been cut down by local Jewish residents, as alleged by left-wing groups and the international media, or by villagers seeking compensation.... Police investigators last year found hundreds of trees that had allegedly been cut by Jewish residents to have actually been pruned by their owners. [Arutz-7 2002].

And here, a different type of response to the olive uprooting phenomenon:

We must look severely upon the attacks on olive harvesters. For Palestinian farmers, the olive harvest is a festival and a cultural event that goes beyond the purely economic dimension. In the future, all necessary steps will be taken to prevent the recurrence of such incidents. [Sharon, B'Tselem 2002: 19] 
This statement was made by no less than Ariel Sharon, Israel's then prime minister. Similarly, in an unusual show of support, a task force of the Kibbutz Movement accompanied Palestinian farmers to the harvest site with the explicit purpose of facilitating their access to their agricultural lands and protecting them from settler violence. The same task force, led by Yoel Marshak, also organized 10,000 volunteers to help the farmers of the Gush Katif settlements in the Gaza Strip relocate their hothouses to the Negev. "There are ... those who come to help prevent hunger among the Palestinians, and those who come for political reasons. I belong to the first group," claims Marshak (Ha'aretz 2006d, 2006e; also discussed in Telephone interview with Uri Pinkerfield, member of this task force, August 20, 2006).

In contrast, international human rights activists seem less concerned by the physical and economic damage caused by the uprootings and more by the emotional and symbolic damages of these acts. In the words of human rights activist Christy Bischoff, "As we approached the woman sitting by the 102 olive trees that the settlers cut the night before, I saw the tears rolling down [her] face as she stared ahead. We were coming to pay our respects; it was a funeral, a graveyard where the 30-year-old trees were slaughtered” (see Amayreh 2006).

Other human rights groups provide different rationales for their support of Palestinian farmers. For example, Rabbi Arik Ascherman of Rabbis for Human Rights has made it very clear that his organization is not involved in this struggle for the sake of trees: "We are not an environmental organization, and have no specific interest in trees, but rather in the struggle over land” (Interview, Burin Village, Occupied West Bank, August 14, 2006). One of the central activities of Rabbis for Human Rights is the replanting of new 
olive trees in place of the uprooted ones. In certain years, activists of the organization planted more than 25 thousand olive trees in place of those damaged or uprooted. However, in December 2008 Ascherman informed me that the organization was only able to raise enough money to plant 3,000 trees that year. Importantly, rather than replanting according to the particular agricultural needs of the farmer or the village, Rabbis for Human Rights requires that the Palestinians plant the trees donated by the organization in the "right place."

What is a "right place"? This was the focus of a conversation between Ascherman and Nidal - the head of Burin’s Village Council - that I witnessed in Burin in August 2006. Nidal asked for three hundred olive trees to replace the uprooted ones, to which Ascherman replied by promising that he will get the new trees there by Sunday, "rain or shine.” However, he qualified, "I will donate these trees with one condition: that they don't just serve farmers from the village, but that they are planted either in the areas that are nearest to the settlements or in the [exact] location from which the trees were uprooted, and not just anywhere.” This conforms with the mission of the organization, which is not environmental, as Ascherman clarified above, but rather focused on the unjust appropriation of Palestinian land. The olive trees, yet again, are fought over not for their own sake but for what they have come to represent and embody.

In a later conversation conducted that same day, Rabbi Ascherman and two other heads of Village Councils negotiated the number of trees that Rabbis for Human Rights would provide for that particular season. During the conversation, the head of the Village Council of Salem, where two thousand olive trees had been uprooted around that time, revealed that he had already secured one thousand trees from two different sources. In 
response, Ascherman clarified that "there is a long list of villages waiting for our trees; so if you have trees from another source, I can give mine to other villages." Evidently, even the project of replanting olive trees involves multiple negotiations. Next, Ascherman spoke with the head of Yanun's Village Council, who refused to take any of Ascherman's trees. When he noticed my surprise at this, Ascherman explained, "Since their village is near a very intense conflict zone they are not sure whether or not they will be able to cultivate the land. They don't want to plant trees and then not be able to take care of them.” Here, then, the trees themselves again assume importance and not merely as tools for grabbing land.

Another sensitive topic on the issue of trees has been the geographic source of these trees. Ascherman assured me that the olive trees that Rabbis for Human Rights donates to Palestinian villages are Israeli olive trees, "born and raised" in Jewish Israeli nurseries only. He presents this as a type of distributive justice: the Palestinian olive trees, uprooted by Jewish people, are now replaced by Jewish olive trees replanted by Palestinian people.

Despite the outcry in the international Jewish community over the uprooting of Palestinian olive trees by Jewish settlers, and despite the wide embrace of Palestinian farmers by numerous human rights groups and by Israel's Kibbutz Movement, the sabotage of olive trees is still an everyday occurrence in the West Bank. As a result, Palestinian access to agricultural land is frequently jeopardized. Israel’s Attorney General Menachem Mazuz acknowledged the gravity of these occurrences, stating that they are "part of a wider phenomenon of a lack of law enforcement against Israelis in the territories" and that "there’s a pervasive feeling of lawlessness [there]” (Ha'aretz 2006a). For this reason, in 2006 Mazuz instructed the Israeli cabinet to compensate Palestinians 
whose olive trees were damaged by the settlers and declared that "[a]ll security and law enforcement officials must devote themselves to a determined struggle against this grave phenomenon, and those responsible must be caught and brought to trial” (Ha'aretz 2006a). Mazuz also ordered Israel's security forces to increase their presence in those areas where trees have been destroyed, to carry out a policy of quick and effective arrests, and to compensate Palestinian tree owners.

Almost three years later, Ruthie Kedar, executive director of human rights organization Yesh Din, informs me that the situation has steadily deteriorated rather than improved.

Israeli soldiers, she says, either don’t intervene in the face of settler harassment or join in. ${ }^{5}$ For example,

On June 1, 2009 there was a big fire in the village of Burin. My colleague and I got up and drove there to see if we could help with anything. When we got there the settlers were standing in one corner of the road, and the soldiers on the other side. The soldiers prevented the Palestinians from using the fire engine that was standing there, and the fire just kept going until it died down on its own. [Telephone interview, June 23, 2009]

Rabbi Ascherman is less explicit about the cooperation between the settlers and the Israeli army:

I don't think the army is officially cooperating with the settlers, ... [but] it is hard to know what their policy really is and what is the wink and nudge kind of system where you turn a blind eye, and where low-rank soldiers were doing something that is against the wishes of their commanders. All three happen, and it is very hard to know which is happening in any given situation. [Telephone interview, December 23, 2008]

\section{HCJ 9593/04: "Friction Zones" and "Timetables"}

According to a number of sources, Israel's administration of Palestinian access to agricultural lands was quite disorganized until 2002 (Interview, Limor Yehouda (attorney for Association for Civil Rights in Israel), Jerusalem, December 20, 2005; Occupation 
Magazine n.d.). Before then, Rabbis for Human Rights worked both with Israel's Defense Forces and with the Israeli police to coordinate their assistance in cases of "harvest trouble," namely the interruption of Palestinian harvest by the New Settlers. Although both agencies were more inclined to provide assistance when Jewish Israelis were involved in any capacity, Rabbi Ascherman stated that it was also clear that "while Israel Defense Forces defined their job as mainly to protect Israelis..., the police understood to a much greater extent that their job was to protect the law and enforce it in all directions" (Interview, Jerusalem, December 15, 2005).

In 2002, the rules of the game changed considerably. Instead of being granted protection in direct response to their demands, the Palestinians became responsible for initiating requests for protection through a rigid and complicated permit system. This coordination process operated on the underlying assumption that Palestinian land cannot be protected at all times with no regard to the cost. Rabbi Ascherman disagreed with this assumption, stating that "Palestinians should be able to go to their land... without coordination, and they should be able to sleep at night...knowing that someone is making sure that their trees are not chopped down” (Interview, Jerusalem, December 15, 2005).

Rabbi Ascherman's view was the foundation for the petition submitted by Rabbis for Human Rights to Israel's Supreme Court of Justice on behalf of Palestinian farmers, focusing on the Nablus region and the area of Hebron. The Association for Civil Rights in Israel (the Israeli equivalent of the ACLU) represented Rabbis for Human Rights in this case. The petition framed the right of Palestinians to access their land as a fundamental human rights issue, basing it on a property rights framework. Ascherman adds in an interview, “As far as we're concerned, if Palestinians want to go and have a 
picnic under their trees or to go and sit under their trees and look at clouds it's their right. And the army must be there to protect that right ... 365 days a year" (Interview, Jerusalem, December 15, 2005).

On June 26, 2006, Justices Dorit Beinisch, Eliezer Rivlin, and Salim Joubran of Israel's Supreme Court ruled that "a policy that prevents Palestinian residents from accessing those lands that belonged to them in the name of their own defense is like a policy forbidding someone from entering his home to protect him from a thief,” and that such policy "is extremely unfair and represents a severe violation of basic rights through giving in to [settler] violence and criminal acts" (HCJ 9593/04 Murar et al. v. IDF Commander for Judea and Samaria, published 26/06/2006). The court thereby required Israel's Defense Forces to do everything in its power to support olive cultivation by Palestinians. The following two subsections explore how such legal protection, despite being well-intentioned, has merely furthered Israel's spatial and temporal control over the everyday life of Palestinians in the occupied West Bank. This has happened through the regulation of friction zones (space) and timetables (time) that pertain to trees.

\section{Friction Zones (Ezorei Hikuch)}

One of the outcomes of the new mandatory coordination system established in 2002 has been a corresponding spatial vocabulary developed by Israel's Defense Forces. A central military term introduced in this context is ezorei hikuch (friction zones), which are defined as zones where the army promises to protect the trees ad hazait haacharon (until the last olive) (Interview, Rabbi Ascherman, Jerusalem, December 15, 2005; see also Ha'aretz 2007a; Taayush 2004; Frish and Shmueli 2002). On maps drawn by Israel's Defense Forces, friction zones are depicted in red. Critics like the Israeli non profit 
organizations Rabbis for Human Right, The Association for Civil Rights in Israel, Yesh Din, Gush Shalom, B'Tselem, Taayush and others have cast doubt on the benefits of the friction zone system.

In response to pressure from the Supreme Court following the petition, Israel's Defense Forces revised the simple division of friction/nonfriction zones into a more complicated system in which, according to Rabbi Ascherman, "the other part of the army's statement is that any place that is not defined as a friction zone they won't bother to guard even if asked.” He mentions that after "a number of attacks last year, I finally got them to realize ... that areas that they didn't define at all as friction areas were actually [places] where there could be a lot of problems. [Interview, December 23, 2008; see also Association for Civil Rights n.d., Palestine News Network 2006, and Yoaz 2004]

Three years later, Ascherman informs me that the problems have changed somewhat. Israel's Defense Forces have been doing a much better job at protecting Palestinian harvesters. At the same time, military commanders increasingly request that Palestinians acquire permits for all areas, not only the red zone per the decision by the Supreme Court. This, Ascherman concludes, is reason enough to go back to court (Interview, December 23, 2008). Either way, in the name of protecting the right of Palestinians to access olive trees, and in the name of Palestinian tree protection in general, Israel's Defense Forces have thus revised their administration so that it further fragments this already fractured space. ${ }^{6}$ Since the petition, then, the vernacular landscape has been reduced to an abstract, two-dimensional series of blue, red, and yellow zones that have come to represent regimented codes of mandatory spatial conduct (see also Braverman 2007). 


\section{Timetables (Luzim)}

The petition's indirect result, namely the alienation Palestinians from their space, is coupled with their alienation from local time. One example of this discrepancy between local and military time regimes is provided by B'Tselem. While Israel's Defense Forces claim that olive groves require access only during the harvest season, B'Tselem notes that this claim is inaccurate: "Cultivation of the orchards throughout the year, such as plowing, pruning, and weeding, greatly affect the yield and quality of the olives and the oil” (B'Tselem 2004). Palestinians have also claimed that Israeli authorities were consistently ignoring the type of crops they cultivate and underestimating the period of time required for cultivation. In effect, Israel's arbitrary timetables have been invalidating the Palestinian's vernacular sense of time. ${ }^{7}$ In other words, to manage the everyday tasks that were once manageable without the mediation of military vocabulary, Palestinians are now being forced to use the military's timetable and the assistance of intermediary organizations (see also Handel 2007).

Rabbi Ascherman also provides a small but illustrative example of one possible meaning of local time in this context. When he asks the head of Burin's Village Council by which date the latter would like to have the trees ready for planting, the village head replies, “After the big rain,” a schedule which the Rabbi contrasts with the military’s approach:

The Samaria branch of Israel's Defense Forces has come up with a timetable scheme, which means that they take responsibility for protecting the harvesters, but only when the harvesters comply with certain time requirements: for example, this and this village has [to harvest] from this date to this date. [The military timetable] is mostly arbitrary: they make it seem as if their timetable is coordinated with the Palestinians, but in fact that doesn't happen. [Interview, Jerusalem, December 15, 2005] 
Similarly, E.P. Thompson (1967) notes the modern transformation from agricultural time, structured by seasons and associated with varied tasks, to "clock time," which organizes the working hours of industry to extract maximum surplus value from the workers. In this case, Israel has introduced into the occupied West Bank a new system of timetables (luzim) that impose a rigid allocation of harvest days.

So although Rabbis for Human Rights and the Association for Civil Rights in Israel won the legal battle against the State of Israel, thereby forcing the Israeli military to protect Palestinian access to and cultivation of land, the on-the-ground picture is much less optimistic. Lawyer Yehouda, who took the case to court, describes some of the underlying effects of the court's decision:

You're a farmer, and you want to go and cultivate your land, but now you have to work through these overwhelming bureaucratic structures just to go on living your daily life.... We're talking about an entire bureaucratic structure that has developed as a response [to the olive uprooting by the settlers]. [Interview, Jerusalem, December 20, 2005]

Yehouda adds that the court decision "totally changed people's lives over there. It changed the nature of everyday life in the village" (emphasis added). Instead of introducing stability and order, Israel's bureaucratic apparatus has evoked much chaos and misunderstanding, Yehouda says. “[Y]ou just can’t administer hundreds, or even thousands, of farmers that, for the most part, don't want to be administered," she concludes.

\section{Conclusion}

This article explored the legal geography - namely the interrelations between the legalities and spatialities - of the olive tree. It did so, mainly, by discussing the olive's 
physical, imaginary, and regulatory dimensions. In particular, the article showed that the olive's importance in the national Palestinian scheme, although definitely a result of economic interests and historic tradition, is at the same time also given greater emphasis by Israel's deadly targeting of the olive tree as a symbolic and physical embodiment of Palestinian national resistance. Simultaneously, the spatial and temporal regulation of Palestinian conduct with regard to their olive groves has had a devastating effect on their relationship to their land. Under the new separation regime, Palestinian access to agricultural lands often requires a series of certificates, an ability to decipher countless directives, and a comprehensive engagement with Israel's military permit and gate bureaucracy (see Abu-Zahra 2008; Braverman in press.c; Gordon 2008; Kelly 2006; Weizman 2007). In effect, the Palestinian relationship to trees, and especially to the olive tree, is now mediated and controlled through Israel's detailed and often incomprehensible military regulations. This effect is probably more acute and long lasting than even the most extreme of olive uprooting practices carried out by the State of Israel or by the New Settlers.

More generally, although both the New Settlers and the human rights activists interviewed here have insisted that the Israeli/Palestinian war is not really about trees but about land, it is nonetheless clear that the emotional, cultural, ritualistic, and economic significance of the tree has been at the forefront of their actions. The Palestinian farmers interviewed here would never have claimed that trees are unimportant in this battle. However, they would probably also see clearly the connection between the trees and the overall power struggle over land, autonomy, identity, and power at stake. Conducting the 
war over land through tree warfare - rather than simply taking over the land with the force of guns and bulldozers, for example - has helped to fix and naturalize the importance of trees in Israel/Palestine as well as to underscore the dramatic and central role that land still performs in this region.

\section{Notes}

1. The quantitative data in this paragraph are from B'Tselem 2002, which quotes from the Palestinian Central Bureau of Statistics (PCBS) and the Palestinian Agricultural Relief Committee (PARC).

2. This is from an interview by B’Tselem, Case 2002, case 122, “Tapuah Settlers’ Abuse of Palestinian Olive Pickers from Yasuf Village and Theft of Their Crop" (courtesy of Nimrod Amzalek, B'Tselem). The B'Tselem website contains a number of interviews.

3. See B'Tselem n.d.a (statistics updated in 2007 and 2008) at http://www.btselem.org/english/Separation_Barrier/Statistics.asp, accessed June 23, 2009.

4. B'Tselem wrote an official letter to the authorities on this topic, which can be found at http://www.btselem.org/english/Settler_Violence/20090604_settler_violence_following_ evacuation_of_outposts.asp, B’Tselem 2009. See also video recording of settlers setting fire to Palestinian orchards in the Nablus area (B'Tselem 2009).

5. See also the article about the situation entitled "Ahead of the olive harvest 2007: Yesh Din's demands from the security force, October 2007," which can be found at http://www.yesh-din.org/site/index.php?page=law3\&lang=en .

6. The 1993 Oslo Accord divides Palestinian space into A, B, and C Areas. Areas A and $\mathrm{B}$ of the occupied Palestinian territories are largely urban, and most of the agricultural Palestinian land is situated in Area C, which is further divided into C1, C2, C3, and so forth. For a critical account of Israel's creative spatial design of the West Bank landscape and its pervasive separation regime, see Weizman (2007) and Gordon (2008).

7. Another interesting dimension of a time-related struggle in this context actually pertains to Palestinian "clock time." Since "extra virgin" olive oil (which depends on the oil's low acidity and is the most desired oil in elite markets worldwide) depends on timely production and shipping, the occupation's general obstructions of movement have also effectively obstructed Palestinians from realizing the market value of their olive oil (Meneley 2008: 21). The economic aspects of olive cultivation in Israel (but not in the occupied West Bank) are further discussed in the epilogue of Braverman 2009.

\section{References Cited}

Abu-Zahra, Nadia

2008 IDs and Territory: Population Control for Resource Appropriation. In War, 
Citizenship Territory. Deborah Cohen and Emily Gilbert eds. Pp. 303-326. New York: Routledge.

Amayreh, Khalid

2006 Israeli Army Uprooting Olive Groves. Al-Jazeera Online, January 12. Cited online at http://cosmos.ucc.ie/cs1064/jabowen/IPSC/php/art.php?aid=32260 and http://forums.allaboutjazz.com/showthread.php?t=5423\&page=141, accessed October 17, 2009.

Arutz-7

2002 Yitzhar Resident Acquitted after Left-Wing/Arab Claims Rejected. January 2. Ashrawi, Hanan Mikhail

1978 The Contemporary Palestinian Poets of Occupation. Journal of Palestine S tudies 7(3): 77-101.

Association for Civil Rights

n.d. Rights Leaflets to Palestinian Farmers. Electronic document, http://www.acri.org.il/eng/Story.aspx?id=616, accessed October 17, 2009.

Bardenstein, Carol B.

1998 Threads of Memory and Discourses of Rootedness: Of Trees, Oranges, and the Prickly-Pear Cactus in Israel/ Palestine. Edebiyat 8(1): 1-36.

1999 Trees, Forests, and the Shaping of Palestinian and Collective Memory. In Acts of Memory: Cultural Recall and the Present. Mieke Bal, Jonathan Crewe, and Leo Spitzer. eds. Pp. 148-168. Hanover, NH: University Press of New England.

Blomley, Nicholas

1994 Law, Space, and the Geographies of Power. New York: Guilford Press.

Blomley, Nicholas, David Delaney and Richard Ford, eds.

2001 The Legal Geographies Reader: Law, Power, and Space. Cambridge, MA: Blackwell.

Braverman, Irus

2007 Powers of Illegality: House Demolitions and Resistance in East Jerusalem. Law and Social Inquiry 32(2): 333-372.

2008 The Tree is the Enemy Soldier: A Sociolegal Making of War Landscapes in the Occupied West Bank. Law \& Society Review 42(3): 449-482.

2009 Planted Flags: Trees, Land, and Law in Israel/Palestine. New York: Cambridge University Press.

In press.a Planting the Promised Landscape. Natural Resources Journal. 
In press.b Hidden in Plain View: Legal Geography from a Visual Perspective. Journal of Law, Culture, and the Humanities.

In press.c Civilized Borders: A Study of Israel's New Border Regime. Antipode: A Radical Journal of Geography.

B'Tselem

2002 Report: Foreseen but not Prevented: The Israeli Law Enforcement

Authorities' Handling of Settler Attacks on Olive Harvesters.

Electronic document, www.btselem.org/Download/200211_Olive_Harvest_Eng.pdf, accessed October 17, 2009.

2004 Report: Not All it Seems: Preventing Palestinians Access to their Lands

West of the Separation Barrier in the Tulkarm-Qalqiliya Area. Electronic document, http://www.btselem.org/english/publications/summaries/200406_qalqiliya _tulkarm_barrrier.asp, accessed October 17, 2009.

2009 Letter to the Authorities. Electronic document, http://www.btselem.org/english/Settler_Violence/20090604_settler_violen ce_following_evacuation_of_outposts.asp, accessed June 22, 2009.

n.d.a Statistics. Electronic document, http://www.btselem.org/english/Separation_Barrier/Statistics.asp, accessed June 23, 2009.

n.d.b Settlers attack Palestinian farmers on their land: Testimony. Electronic document,http://www.btselem.org/English/Testimonies/20090110_Havat_ Gilad_Settlers_drive_farmers_off_their_land.asp, accessed June 23, 2009.

Callon, Michel

1986 Some Elements of a Sociology of Translation: Domestication of the Scallops and the Fisherman of St. Brieuc Bay. In Power, Action and Belief: A New Sociology of Knowledge. John Law ed. Pp. 196-233. London: Routledge.

Cohen, Shaul Efraim

1993 The Politics of Planting: Israeli-Palestinian Competition for Control of Land in the Jerusalem Periphery, Chicago: University of Chicago Press.

Delaney, David

1998 Race, Place, and the Law 1836-1948. Austin: University of Texas Press.

Farah, Najwa Qu'war

1992[1963] The Worst of Two Choices: or, The Forsaken Olive Trees. In Anthology of Modern Palestinian Literature. Salma Khadra Jayyusi ed. 
Pp. 434- 441. New York: Columbia University Press.

Frish, Felix, and Smadar Shmueli

2002 IDF and the Olive Harvest. Ynet, October 22,

at http://www.ynet.co.il/articles/1,7340,L-2194216,00.html, accessed October 17, 2009.

Gordon, Neve

2008 Israel’s Occupation. Berkeley: University of California Press.

Gregory, Derek

2002 Defiled Cities. Singapore Journal of Tropical Geography 24(3): 307-326.

Gush Shalom

2004 The Harvest Coalition. Electronic document, October 15, 2004, http://zope.gush-shalom.org/home/he/channels/press_releases/pr_pr15-102004, accessed October 17, 2009.

Ha’aretz

2006a Mazuz Urges Compensation for Arabs Whose Olive Trees Axed. January 8.

2006b Yesha: Some of the West Bank Olive Trees Felled by Palestinians. January 10.

2006c It's Not the Olive Trees. January 11.

2006d Witnesses Say Settlers Attacked Palestinian Farmers Near Nablus. April 1.

2006e Salem: A Scene of Struggle between Settlers and Volunteers. April 17.

2006f High Court Orders IDF to Protect Palestinian Farmers from Settlers. June 26.

2008a Border Control: In the Name of the Mother. October 10.

2008b Settlers Preparing for War, Says Shin-Bet Chief. November 3.

Handel, Ariel

2007 Controlling the Space through the Space: Uncertainty as a Technology of Control. Theory and Criticism 31: 101-126.

Harlow, Barbara

1987 Resistance Literature. New York: Routledge.

Israeli Ministry of Defense 
n.d. Israel's

http://www.securityfence.mod.gov.il/Pages/ENG/questions.htm\#q25, accessed June 23, 2009.

Kanafani, Ghassan

1958 Men in the Sun, and Other Palestinian Stories. Boulder, CO: Lynne Rienner Publishers.

Kelly, Tobias

2006 Documented Lives: Fear and the Uncertainties of Law during the Second Palestinian Intifada. Royal Anthropological Institute 12: 89107.

Long, Joanna Claire

2005 (En)planting Israel: Jewish National Fund Forestry and the Naturalisation of Zionism. MA Thesis, University of British Columbia.

McClatchy Newspapers

2008 Radical Jewish Settlers Threaten to Fight Israeli Army. December 3.

Meneley, Anne

2008 Time in a Bottle: The Uneasy Circulation of Palestinian Olive Oil. Middle East Report 248: 18-23.

Nassar, Jamal Raji and Roger Heacock

1990 Intifada: Palestine at the Crossroads. Westport, CT: Greenwood Publishing.

Occupation Magazine

n.d. No Peace Under the Olive Tree.

http://www.kibush.co.il/show_file.asp?num=282 (Hebrew), accessed October 17, 2009.

Palestine News Network

2006 Electronic document. October 1, http://hebrew.pnn.ps/index.php?option=com_content\&task=view\&id=144\&It emid=34 (Hebrew), accessed October 17, 2009.

Slyomovics, Susan

1998 The Object of Memory: Arab and Jew Narrate the Palestinian Village. Philadelphia: University of Pennsylvania Press.

Swedenburg, Ted

1990 The Palestinian Peasant as National Sigffier. Anthropological Quarterly 63(1): 18-30. 
Taayush - Arab Jewish Partnership

2003 Olive Harvest $2004 . \quad$ Electronic document, http://www.taayush.org/new/20041000-harvest.html\#vulgar,

accessed October 17, 2009.

Telegraph

2002 Palestinian Olive Trees Sold to Rich Israelis. November 28.

Thompson, E.P.

1967 Time, Work-Discipline, and Industrial Capitalism. Past and Present 38: 57-96.

van der Sluijs, Jeroen, van Eijndhoven, Josée, Shackley, Simon and Brian Wynne

1998 Anchoring Devices in Science for Policy. Social Studies of Science 28(2): 291-323.

Weizman, Eyal

2007 Hollow Land: Israel's Architecture of Occupation. New York: Verso.

Yediot Achronot

2005 West Bank Settlers Destroy Palestinian Olive Trees. December 19.

Yesh Din

2007 Ahead of the Olive Harvest 2007: Yesh Din's Demands from the Security

Force, October 2007. Electronic document, http://www.yeshdin.org/site/index.php?page=law3/=en, accessed June 24, 2009.

2008 Open Letter in Hebrew. Electronic document, September 11, 2008, www.yesh-din.org/sys/.../YDOliveletter10Sep08Heb\%5B1\%5D.pdf, accessed October 17, 2009.

Yoaz, Yuval

2004 The Supreme Court. Ha’aretz, November 2.

Zerubavel, Yael

1995 Recovered Roots: Collective Memory and the Making of Israeli National Tradition. Chicago: University of Chicago Press. 